\title{
Effect of Nursing Management and Skeletal Size at Weaning on Puberty, Skeletal Growth Rate, and Milk Production During First Lactation of Dairy Heifers
}

\author{
A. Shamay, ${ }^{1}$ D. Werner ${ }^{2}$ U. Moallem, ${ }^{1}$ H. Barash, ${ }^{1}$ and I. Bruckental ${ }^{1}$ \\ ${ }^{1}$ Institute of Animal Science, Agricultural Research Organization, The Volcani Center \\ ${ }^{2}$ Department of Dairy Cattle, Extension Service. Ministry of Agriculture, Bet Dagan 50250, Israel
}

\begin{abstract}
Forty Israeli-Holstein 5-d-old calves were used to determine the effect of increasing calf body weight (BW) and skeletal size during the nursing period on age and skeletal size at puberty and on skeletal size and performance during first lactation. The calves were randomly allotted to 2 experimental groups as follows: milk replacer (MR) [calves were given $0.450 \mathrm{~kg} / \mathrm{d}$ dry matter of milk replacer for the first $50 \mathrm{~d}$ of life] and milk-fed (MF) [calves had free access to milk in two 30-min meals/d]. From weaning to $180 \mathrm{~d}$ of age, all calves were fed the same diet. At $180 \mathrm{~d}$ of age, the MR and MF calves were each divided into 2 equal subgroups: one subgroup from each treatment was given only growing ration, and the other was given the same ration supplemented with fish meal to supply $2 \%$ crude protein (CP) (treatments MR $+\mathrm{CP}$ and $\mathrm{MF}+\mathrm{CP}$, respectively). Finally, at $270 \mathrm{~d}$ of age, all calves were housed together and fed a growing heifer's ration until first calving. During the entire nursing period, the MF calves consumed 9.8\% more DM, $39.7 \%$ more $\mathrm{CP}$, and $52.4 \%$ more metabolizable energy than the MR calves. At $60 \mathrm{~d}$ of age, BW and all skeletal parameters were higher in the MF calves than in the MR calves. During the entire rearing period (60 to 550 d), the average BW of the MF calves was greater by 16 $\mathrm{kg}$ than the BW of the MR calves. Nursing management did not affect differences in skeletal parameters at calving. Average age at puberty onset was $272 \pm 26.8 \mathrm{~d}$; MF calves reached puberty $23 \mathrm{~d}$ earlier than MR calves. Yields of milk (kg/305 d) and fat-corrected milk (FCM, $\mathrm{kg} / \mathrm{d}$ ) were greater for the MF + CP heifers than for the MR heifers. It was concluded that nursing by ad libitum milk, as compared with milk replacer, affected BW but not skeletal size of the adult animal, decreased age of puberty onset, and increased FCM yield at first lactation. Supplementing the diet with $2 \% \mathrm{CP}$ during the prepubertal period increased BW but not skeletal size
\end{abstract}

Received August 1, 2004.

Accepted November 18, 2004.

Corresponding author: A. Shamay; e-mail: shamay@agri.huji.ac.il. of the adult animal and 305-d milk and FCM yields during first lactation.

(Key words: nursing management, skeletal growth, milk production, puberty)

Abbreviation key: $\mathbf{H G}$ = heart girth, $\mathbf{H W}=$ hip width, $\mathbf{M E}=$ metabolizable energy, $\mathbf{M F}=$ milk fed, $\mathbf{M R}=$ milk replacer, $\mathbf{W H}=$ wither height.

\section{INTRODUCTION}

Replacement heifers represent a large proportion of the total cost of milk production. The optimal age at calving has been between 22 and 24 mo of age (Gardner et al., 1988; Hoffman and Funk, 1992). The positive relationship between BW at parturition and milk yield at first lactation has been well established (Keown and Everett, 1986; Heinrichs and Hargove, 1987; Hoffman and Funk, 1992). In surveys conducted in the United States (Heinrichs and Hargove, 1987; Hoffman, 1997) and Israel (Markusfeld and Ezra, 1993), a positive correlation was found between wither height (WH) of heifers and milk yield of cows. The correlation between WH and milk yield at first lactation was higher than that between BW and milk yield (0.41 vs. 0.34) under management conditions in the United States (Heinrichs and Hargove, 1987). Skeletal size has also been critical in minimizing dystocia (Hoffman, 1997).

According to Johnson and Obest (1984) and Foldager and Sejrsen (1987), a rapid growth rate from 3 to 12 mo of age led to a decrease in milk production, as a result of an increase in the mammary adipose tissue and its parenchymal content (Sejrsen et al., 1982). Moderate feed restriction during the critical period was recommended. However, when a delay was induced in the growth rate of calves, full recovery of skeletal size or BW was not achieved by compensatory feeding, at least during the experimental period. Thus, contradictory management programs are needed to rear a dairy cow that will express its full genetic potential for skeletal size and milk production at 22 mo of age. In the present study, it was hypothesized that skeletal growth rate could be enhanced during the first weeks after birth 
when the growth potential is maximal and the tendency toward fattening is still low (Bar Peled et al., 1997). Later on, toward puberty, a moderate-energy, high-protein ration could help avoid excessive fattening (Drackley, 2001).

The objectives of the present study were to determine the effect of accelerated calf BW gain and skeletal size growth during the nursing period on age and skeletal size at puberty and first calving and performance during the first lactation.

\section{MATERIALS AND METHODS}

\section{Animals and Treatments}

Forty Israeli-Holstein calves ( $5 \mathrm{~d}$ of age) were used for the experiment. The calves were randomly allotted to 2 experimental groups, 20 calves in each, according to BW, WH, heart girth (HG), and hip width (HW). Milk replacer (MR) was fed to control calves until $60 \mathrm{~d}$ of age. The calves were given $0.450 \mathrm{~kg} / \mathrm{d} \mathrm{DM}$ of MR $(96 \% \mathrm{DM})$ that contained $57 \%$ carbohydrates, $12 \%$ fat, $23 \% \mathrm{CP}$, $8 \%$ ash, and $4.1 \mathrm{Mcal}$ metabolizable energy (ME) (DM basis). The daily amount of MR was diluted in $5 \mathrm{~L}$ of water $\left(37^{\circ} \mathrm{C}\right)$ and was given to the calves once daily in a bucket that was equipped with a teat. The other experimental group, milk-fed (MF) calves, was fed until $60 \mathrm{~d}$ of age with ad libitum fresh milk (11.5\% DM) that contained $39.6 \%$ lactose, $28.7 \%$ fat, $27.0 \% \mathrm{CP}, 4.7 \%$ ash, and 5.3 Mcal ME (DM basis) that was offered in two 30min meals/d. The ME contents in DM of milk and MR were calculated according to NRC (1989).

All calves were housed in individual hutches that were equipped with buckets for water and starter mixture. The calves had free access to water and starter mix (Table 1). To reduce weaning stress, milk and MR were reduced gradually during $10 \mathrm{~d}$. From weaning to $180 \mathrm{~d}$ of age, all calves were fed the same diet: from weaning to $90 \mathrm{~d}$, they were given only starter mix; from 90 to $150 \mathrm{~d}$ of age, a 50:50 mix of starter and milking-cow rations; and from 150 to $180 \mathrm{~d}$ of age, the calves were gradually adjusted to growing-heifer rations (Table 1). At $180 \mathrm{~d}$ of age, the MR and MF calves were each divided into 2 subgroups: 10 calves from each treatment were given only a growing ration, and the other 10 calves were given the same ration supplemented with fish meal to supply $2 \% \mathrm{CP}$ (treatments $\mathrm{MR}+\mathrm{CP}$ and $\mathrm{MF}+\mathrm{CP}$, respectively). The calves from each treatment group were randomly allotted to one of these feeding groups according to $\mathrm{BW}, \mathrm{WH}, \mathrm{HG}$, and $\mathrm{HW}$. An elevated dietary CP-to-energy ratio was expected to reduce the heifer's tendency toward fattening during puberty (Drackley, 2001). These heifers were fed the additional protein until $270 \mathrm{~d}$ of age, and then all calves were housed together and fed the same growing-heifer ration until first calving
Table 1. Ingredient and chemical composition of the starter mix, growing-heifer, and milking-cow rations (\% DM).

\begin{tabular}{|c|c|c|c|}
\hline Ration & $\begin{array}{l}\text { Starter } \\
\text { mix }\end{array}$ & $\begin{array}{l}\text { Growing } \\
\text { heifers }\end{array}$ & $\begin{array}{l}\text { Milking } \\
\text { cows }\end{array}$ \\
\hline & & $-(\% \mathrm{DM})$ & 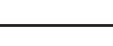 \\
\hline \multicolumn{4}{|l|}{ Ingredient } \\
\hline Corn grain & 28.1 & 10.0 & 23.7 \\
\hline Barley grain & 29.4 & 1.2 & 8.3 \\
\hline Wheat bran & - & 5.0 & - \\
\hline Soybean meal & 12.8 & - & 8.9 \\
\hline Rapeseed meal & - & 3.6 & 1.0 \\
\hline Gluten feed & - & 5.0 & 10.9 \\
\hline Whole cottonseeds & 12.0 & - & 2.8 \\
\hline Coffee waste ${ }^{1}$ & - & 10.0 & - \\
\hline Soybean hulls & - & 2.2 & 1.5 \\
\hline Sunflower seed hulls & - & 18.0 & - \\
\hline Wheat straw & - & 53.0 & 1.5 \\
\hline Vetch hay & 16.1 & - & 2.8 \\
\hline Wheat hay & - & - & 7.6 \\
\hline Wheat silage & - & - & 23.4 \\
\hline Vegetable oil & 0.5 & - & 1.1 \\
\hline $\begin{array}{l}\text { Vitamin and mineral } \\
\text { mix }^{2}\end{array}$ & $1.6^{2}$ & $2.0^{2}$ & $6.9^{3}$ \\
\hline Rumensin ${ }^{3}$ & 0.01 & - & - \\
\hline \multicolumn{4}{|l|}{ Chemical composition } \\
\hline $\mathrm{CP}$ & 18.0 & 13.2 & 16.8 \\
\hline NDF & 23.0 & 58.7 & 30.3 \\
\hline $\mathrm{ME},{ }^{4}, \mathrm{Mcal} / \mathrm{kg}$ of $\mathrm{DM}$ & 3.16 & 2.89 & 3.00 \\
\hline
\end{tabular}

${ }^{1}$ Industrial waste (Elite Ltd, Nazareth, Israel).

${ }^{2}$ Mixture contained 12,800,000 IU/kg vitamin A, 2,560,000 IU/kg vitamin D, 16,000 mg/kg vitamin E, $64.0 \mathrm{~g} / \mathrm{kg} \mathrm{Mn}, 64.0 \mathrm{~g} / \mathrm{kg} \mathrm{Zn}, 64.0$ $\mathrm{g} / \mathrm{kg} \mathrm{Fe}, 32.0 \mathrm{~g} / \mathrm{kg} \mathrm{Cu}, 12.8 \mathrm{~g} / \mathrm{kg} \mathrm{I}, 0.32 \mathrm{~g} / \mathrm{kg} \mathrm{Se}$, and $0.48 \mathrm{~g} / \mathrm{kg}$ Co.

${ }^{3}$ Mixture contained 20,000,000 IU/kg vitamin A, 2,000,000 IU/kg vitamin D, 15,000 mg/kg vitamin E, $6.0 \mathrm{~g} / \mathrm{kg} \mathrm{Mn}, 6.0 \mathrm{~g} / \mathrm{kg} \mathrm{Zn}, 2.0 \mathrm{~g} /$ $\mathrm{kg} \mathrm{Fe}, 0.5 \mathrm{~g} / \mathrm{kg} \mathrm{Cu}, 0.12 \mathrm{~g} / \mathrm{kg} \mathrm{I}, 0.05 \mathrm{~g} / \mathrm{kg} \mathrm{Se}$, and $0.02 \mathrm{~g} / \mathrm{kg} \mathrm{Co}$.

${ }^{4} \mathrm{ME}=$ Metabolizable energy, calculated according to NRC (1989).

(Table 1). The animal trial started in January 1999, and was completed after $>3$ yr, during April 2002.

\section{Experimental Procedure}

The BW, WH, HW, and HG of calves were measured $4 \mathrm{~d}$ after birth, every $2 \mathrm{wk}$ thereafter up to 12 mo of age, and then every 3 mo until 18 mo of age. The WH was measured once more at $660 \mathrm{~d}$ of age. Hip width data were not recorded at $550 \mathrm{~d}$ of age, and this parameter was, therefore, analyzed for only 3 ages. The BCS (ranked on a scale of 1 to 5; Edmonson et al., 1989) was determined every 2 wk. Daily DMI was recorded individually for each calf during the nursing period and from 180 to $270 \mathrm{~d}$ of age; DMI was recorded for each experimental group.

Progesterone was determined in blood sampled weekly from 4 mo of age until puberty, using the radioimmunoassay kit of Diagnostic Products Corporation, (Los Angeles, CA) according to the manufacturer's protocol. Puberty attainment was defined as the time when blood progesterone level reached $1 \mathrm{ng} / \mathrm{mL}$. 
At 13 mo of age, clusters of heifers were given a single 625-ng injection of the $\mathrm{PGF}_{2 \alpha}$ analog cloprostenol (Estrumate; Coopers Animal Health Ltd., Berkhamsted, UK). After the $\mathrm{PGF}_{2 \alpha}$ injection, heifers that exhibited visual signs of estrus and were regarded as being in estrus were inseminated. Heifers that were not in estrus after the first $\mathrm{PGF}_{2 \alpha}$ injection were given a second $\mathrm{PGF}_{2 \alpha}$ injection $14 \mathrm{~d}$ after the first one and were inseminated after showing signs of estrus. After calving, heifer recovery and performance during first lactation were monitored. The heifers were milked 3 times each day, and daily milk yield and BW were recorded by the Afimilk system (S.A.E. Afikim, Kibbutz Afikim, Israel). Milk composition was determined monthly by infrared procedure at the Israeli Cattle Association Laboratories (Caesarea, Israel).

\section{Calculations and Statistical Analyses}

All statistical analyses were conducted with JMP software (SAS, 2000). Estimations of BW, WH, HG, and HW at $180,270,340$, and $550 \mathrm{~d}$ of age were made separately for each heifer, by linear regressions (the progress of $\mathrm{BW}, \mathrm{WH}, \mathrm{HG}$, and $\mathrm{HW}$ up to $550 \mathrm{~d}$ of age is not linear, but within a narrower range, a linear regression could explain the direction, and the value estimates were suitable). Four to 6 points surrounding each age estimate were used to create the linear regression.

Data for BW, WH, HG, and HW were subjected to 3-way ANOVA with a repeated-measurements ("splitplot") design: effects of nursing treatment (MR vs. milk), of dietary protein supplementation (supplementation vs. no supplementation), and of their interaction were tested against the between-heifer error, and age (180, 270,340 , or $550 \mathrm{~d}$ ) with all interactions tested against between-age within-heifer error. The statistical model was:

$$
\begin{gathered}
\mathrm{Y}_{\mathrm{ijkl}}=\mu+\alpha \mathrm{I}+\gamma \mathrm{j}+\gamma \alpha_{\mathrm{ij}}+\mathrm{e}_{\mathrm{ijk}}^{1}+\delta_{\mathrm{l}}+\alpha \delta_{\mathrm{il}} \\
+\gamma \delta_{\mathrm{j}} \mathrm{l}+\alpha \gamma \delta_{\mathrm{ijl}}+\mathrm{e}_{\mathrm{ijkl}}^{2}
\end{gathered}
$$

where $\mu=$ mean of all trial data; $\alpha_{\mathrm{i}}=$ difference between the mean of nursing treatment $i$ and the trial mean; $\gamma_{j}=$ difference between the mean of protein treatment $j$ and the trial mean; $\gamma \alpha_{\mathrm{ij}}=$ interaction between nursing and protein treatments; $e_{i \mathrm{ijk}}^{1}=$ variance between heifers from nursing treatment $\mathrm{i}$ and protein treatment $\mathrm{j}$ (Error 1); $\delta_{1}=$ difference between the mean at age $l$ and the trial mean; $\alpha \delta_{\mathrm{il}}=$ interaction between nursing treatment and age; $\gamma \delta_{\mathrm{jl}}=$ interaction between protein treatment and age; $\alpha \gamma \delta_{\mathrm{ijl}}=$ interaction among nursing treatment, protein treatment, and age, and $\mathrm{e}_{\mathrm{ijk} \mathrm{kl}}^{2}=$ residual of the measurements of "nursing" i, "protein" j, and "age" l(Error 2).
Table 2 Averages of DM, CP, and metabolizable energy (ME) intakes of calves nursed with either milk replacer (MR) or an ad libitum milk supply (MF) during the nursing period (5 to $60 \mathrm{~d}$ of age; $\mathrm{n}=20$ animals per treatment).

\begin{tabular}{lrrr}
\hline & \multicolumn{2}{c}{ Treatment } & \\
\cline { 2 - 3 } & $\mathrm{MR}$ & $\mathrm{MF}$ & SEM \\
\hline Intake & & & \\
Milk or MR (DM), kg & $24.8^{\mathrm{b}}$ & $54.7^{\mathrm{a}}$ & 4.4 \\
Starter mix, kg & $35.7^{\mathrm{a}}$ & $11.7^{\mathrm{b}}$ & 1.9 \\
Total DM, ${ }^{1} \mathrm{~kg}$ & $60.5^{\mathrm{b}}$ & $66.4^{\mathrm{a}}$ & 4.9 \\
Total CP, ${ }^{1} \mathrm{~kg}$ & $12.1^{\mathrm{b}}$ & $16.9^{\mathrm{a}}$ & 1.2 \\
ME, ${ }^{2}$ Mcal & $214.5^{\mathrm{b}}$ & $326.9^{\mathrm{a}}$ & 21.6 \\
\hline
\end{tabular}

${ }^{\mathrm{a}, \mathrm{b}}$ Means in a row with different letters differ $(P<0.05)$.

${ }^{1}$ Including DM and CP of the solid and liquid feeds.

${ }^{2}$ Calculated according to NRC (1989).

Milk, fat, and protein yield results were adjusted for each individual heifer for calving age and month, as well as for parity using multiplicative factors (Ezra et al., 1987).

Total adjusted milk yield up to $305 \mathrm{~d}$ was subjected to 2-way ANOVA with nursing treatment and protein treatment as main effects. The interaction of these effects was also tested. The statistical model was

$$
\mathrm{Y}_{\mathrm{ijkl}}=\mu+\alpha \mathrm{I}+\gamma_{\mathrm{j}}+\gamma \alpha_{\mathrm{ij}}+\mathrm{e}_{\mathrm{ijk}}
$$

where $\mu=$ mean of all trial data, $\alpha_{\mathrm{i}}=$ difference between the mean of nursing treatment $i$ and the trial mean, $\gamma_{j}=$ difference between the mean of protein treatment $j$ and the trial mean, $\gamma \alpha_{\mathrm{ij}}=$ interaction between "nursing" and "protein," and $\mathrm{e}_{\mathrm{ijkl}}=$ residual of the measurements of nursing treatment $\mathrm{i}$ and protein treatment $\mathrm{j}$ (error).

\section{RESULTS}

\section{Feed Consumption and Growth Rate During Nursing}

During the 60-d nursing period, the MR and MF calves consumed an average 24.8 and $54.7 \mathrm{~kg}$ of DM as liquid, and 35.7 and $11.7 \mathrm{~kg}$ of DM as starter mix, respectively (Table 2). Total DM, CP, and ME intakes of the MR and MF calves were 60.5 and $66.4 \mathrm{~kg}, 12.1$ and $16.9 \mathrm{~kg}$, and 214.5 and 326.9 Mcal, respectively (Table 2). Accordingly, during the entire nursing period, the MF calves consumed $9.8 \%$ more DM, 39.7\% more CP, and $52.4 \%$ more $(P<0.05) \mathrm{ME}$ than the MR calves. At $60 \mathrm{~d}$ of age, BW and all skeletal parameters of the MF calves were significantly greater $(P<0.05)$ than those of the MR calves (Table 3).

\section{Feed Consumption During the Rearing Period}

From 150 to $300 \mathrm{~d}$ of age, the calves were group-fed, and differences in DMI between treatments could not 
Table 3. Body measurement averages of calves nursed with either milk replacer (MR) or an ad libitum milk supply (MF) during the nursing period ( 5 to $60 \mathrm{~d}$ of age; $\mathrm{n}=10$ animals per treatment).

\begin{tabular}{|c|c|c|c|c|c|c|}
\hline & \multicolumn{3}{|c|}{$5 \mathrm{~d}$ of age } & \multicolumn{3}{|c|}{$60 \mathrm{~d}$ of age } \\
\hline & \multicolumn{2}{|c|}{ Treatment } & \multirow[b]{2}{*}{ SEM } & \multicolumn{2}{|c|}{ Treatment } & \multirow[b]{2}{*}{ SEM } \\
\hline & MR & $\mathrm{MF}$ & & MR & $\mathrm{MF}$ & \\
\hline $\mathrm{BW}, \mathrm{kg}$ & 37.0 & 35.5 & 5.1 & $69.5^{\mathrm{b}}$ & $84.0^{\mathrm{a}}$ & 1.90 \\
\hline Withers height, $\mathrm{cm}$ & 73.5 & 71.8 & 2.6 & $82.0^{\mathrm{b}}$ & $84.6^{\mathrm{a}}$ & 0.75 \\
\hline Hip width, cm & 19.5 & 18.8 & 1.3 & $23.3^{\mathrm{b}}$ & $24.8^{\mathrm{a}}$ & 0.26 \\
\hline Heart girth, $\mathrm{cm}$ & 73.6 & 71.7 & 2.8 & $88.4^{\mathrm{b}}$ & $95.2^{\mathrm{a}}$ & 0.88 \\
\hline
\end{tabular}

${ }^{\mathrm{a}, \mathrm{b}}$ Means in a row followed by different letters differ $(P<0.05)$.

be subjected to statistical analysis. Accordingly, acrosstreatment average daily DMI for 150 to 180,180 to 270 , and 270 to $300 \mathrm{~d}$ of age were $6.41,7.71$, and $9.73 \mathrm{~kg}$, respectively. From 180 to $270 \mathrm{~d}$ of age, when the diets of 2 of the subgroups were supplemented with fish meal protein, $\mathrm{DMI}$ of the $\mathrm{MR}+\mathrm{CP}$ and $\mathrm{MF}+\mathrm{CP}$ calves tended to be lower than those of the MR and MF groups (Figure $1 \mathrm{C}$ ).

\section{BW}

At $180 \mathrm{~d}$ of age, before the division to subgroups, BW and all skeletal measurements of the MF calves were still significantly greater than those of the MR calves (Table 4). Body weight of the MF + CP calves was significantly higher than that of calves on the other treat- ments until $550 \mathrm{~d}$ of age (Table 4). Body weight of the $\mathrm{MR}+\mathrm{CP}$ calves was greater than that of the MR calves from 270 to $550 \mathrm{~d}$ of age and grater than that of the MF calves at only $550 \mathrm{~d}$ of age. Body weight of MF calves was greater than that of MR calves from 180 to $550 \mathrm{~d}$ of age. An average advantage of $16 \mathrm{~kg}$ was found for the MF calves over the MR calves during the entire rearing period ( 60 to $550 \mathrm{~d}$; average of $311 \mathrm{vs.} 327 \mathrm{~kg}$ ); however, the main effect of nursing by milk on BW was significant for $180 \mathrm{~d}(P<0.003)$ and $270 \mathrm{~d}(P<0.01)$ of age only. No nursing $\times$ age interaction was detected. The main effect of supplementing the diet with $2 \%$ of protein on BW was significant for ages $270 \mathrm{~d}(P<0.015), 340 \mathrm{~d}(P$ $<0.008)$, and $550 \mathrm{~d}(P<0.011)$. This effect increased with age (protein $\times$ age interaction; $P<0.012$ ).

Table 4. Least squares means of calves' body measurements from 180 to $550 \mathrm{~d}$ of age ( $\mathrm{n}=10$ animals per treatment).

\begin{tabular}{|c|c|c|c|c|c|c|c|c|}
\hline \multirow[b]{2}{*}{ Age } & \multicolumn{4}{|c|}{ Treatment $^{1}$} & \multirow[b]{2}{*}{ SEM } & \multirow[b]{2}{*}{$P$} & \multicolumn{2}{|c|}{ Main effect } \\
\hline & MR & MF & $\mathrm{MR}+\mathrm{CP}$ & $\mathrm{MF}+\mathrm{CP}$ & & & Milk & Protein \\
\hline & & 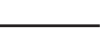 & $(\mathrm{kg})$ & & & & & \\
\hline $180 \mathrm{~d}$ & $178^{\mathrm{b}}$ & $198^{\mathrm{a}}$ & $181^{\mathrm{b}}$ & $201^{\mathrm{a}}$ & 4.79 & 0.001 & 0.003 & NS \\
\hline $270 \mathrm{~d}$ & $262^{\mathrm{c}}$ & $277^{\mathrm{b}}$ & $276^{\mathrm{b}}$ & $297^{\mathrm{a}}$ & 6.30 & 0.010 & 0.01 & 0.02 \\
\hline $340 \mathrm{~d}$ & $318^{\mathrm{c}}$ & $333^{\mathrm{b}}$ & $340^{\mathrm{b}}$ & $353^{\mathrm{a}}$ & 7.17 & 0.020 & NS & 0.01 \\
\hline \multirow[t]{2}{*}{$550 \mathrm{~d}$} & $456^{\mathrm{d}}$ & $465^{\mathrm{c}}$ & $477^{\mathrm{b}}$ & $494^{\mathrm{a}}$ & 9.64 & 0.050 & NS & 0.01 \\
\hline & \multicolumn{4}{|c|}{ Wither height $(\mathrm{cm})$} & & & & \\
\hline $180 \mathrm{~d}$ & $103.4^{\mathrm{b}}$ & $105.9^{\mathrm{a}}$ & $104.1^{\mathrm{b}}$ & $106.4^{\mathrm{a}}$ & 2.63 & 0.050 & 0.02 & NS \\
\hline $270 \mathrm{~d}$ & $118.3^{\mathrm{bc}}$ & $117.6^{\mathrm{c}}$ & $119.3^{\mathrm{b}}$ & $120.6^{\mathrm{a}}$ & 0.64 & 0.020 & NS & 0.02 \\
\hline $340 \mathrm{~d}$ & $125.0^{\mathrm{b}}$ & $124.1^{\mathrm{b}}$ & $125.0^{\mathrm{b}}$ & $126.0^{\mathrm{a}}$ & 0.65 & 0.050 & NS & NS \\
\hline \multirow[t]{2}{*}{$550 \mathrm{~d}$} & $134.3^{\mathrm{a}}$ & $131.8^{\mathrm{b}}$ & $133.7^{\mathrm{a}}$ & $134.4^{\mathrm{a}}$ & 0.74 & 0.050 & NS & NS \\
\hline & \multicolumn{4}{|c|}{ - Heart girth $(\mathrm{cm})$} & & & & \\
\hline $180 \mathrm{~d}$ & $123.5^{\mathrm{b}}$ & $129.3^{\mathrm{a}}$ & $124.8^{\mathrm{b}}$ & $130.6^{\mathrm{a}}$ & 1.29 & 0.010 & 0.001 & NS \\
\hline $270 \mathrm{~d}$ & $141.3^{\mathrm{c}}$ & $143.9^{b}$ & $143.9^{b}$ & $147.4^{\mathrm{a}}$ & 1.23 & 0.020 & 0.008 & 0.02 \\
\hline $340 \mathrm{~d}$ & $153.3^{\mathrm{c}}$ & $155.9^{\mathrm{b}}$ & $155.9^{\mathrm{b}}$ & $157.8^{\mathrm{a}}$ & 1.38 & 0.050 & NS & NS \\
\hline \multirow[t]{2}{*}{$550 \mathrm{~d}$} & $176.6^{\mathrm{c}}$ & $177.0^{\mathrm{bc}}$ & $179.1^{\mathrm{b}}$ & $180.6^{\mathrm{a}}$ & 1.38 & 0.060 & NS & NS \\
\hline & \multicolumn{4}{|c|}{ Hip width $(\mathrm{cm})$} & & & & \\
\hline $180 \mathrm{~d}$ & $32.1^{\mathrm{b}}$ & $33.2^{\mathrm{ab}}$ & $32.4^{\mathrm{b}}$ & $33.7^{\mathrm{a}}$ & 0.30 & 0.0001 & 0.001 & NS \\
\hline $270 \mathrm{~d}$ & $37.4^{\mathrm{bc}}$ & $37.1^{\mathrm{c}}$ & $37.6^{\mathrm{b}}$ & $38.3^{\mathrm{a}}$ & 0.30 & 0.006 & NS & NS \\
\hline $340 \mathrm{~d}$ & $39.4^{\mathrm{b}}$ & $39.6^{\mathrm{b}}$ & $40.1^{b}$ & $40.5^{\mathrm{a}}$ & 0.27 & 0.090 & NS & 0.01 \\
\hline
\end{tabular}

a,b,c,d Means in a row with different letters differ $(P<0.05)$.

${ }^{1} \mathrm{MR}=$ Nursed with milk replacer; $\mathrm{MF}=$ milk-fed, nursed with an ad libitum milk supply; $\mathrm{MR}+\mathrm{CP}=$ MR diet supplemented with $2 \% \mathrm{CP}$; and $\mathrm{MF}+\mathrm{CP}=$ milk diet supplemented with $2 \% \mathrm{CP}$. 
A
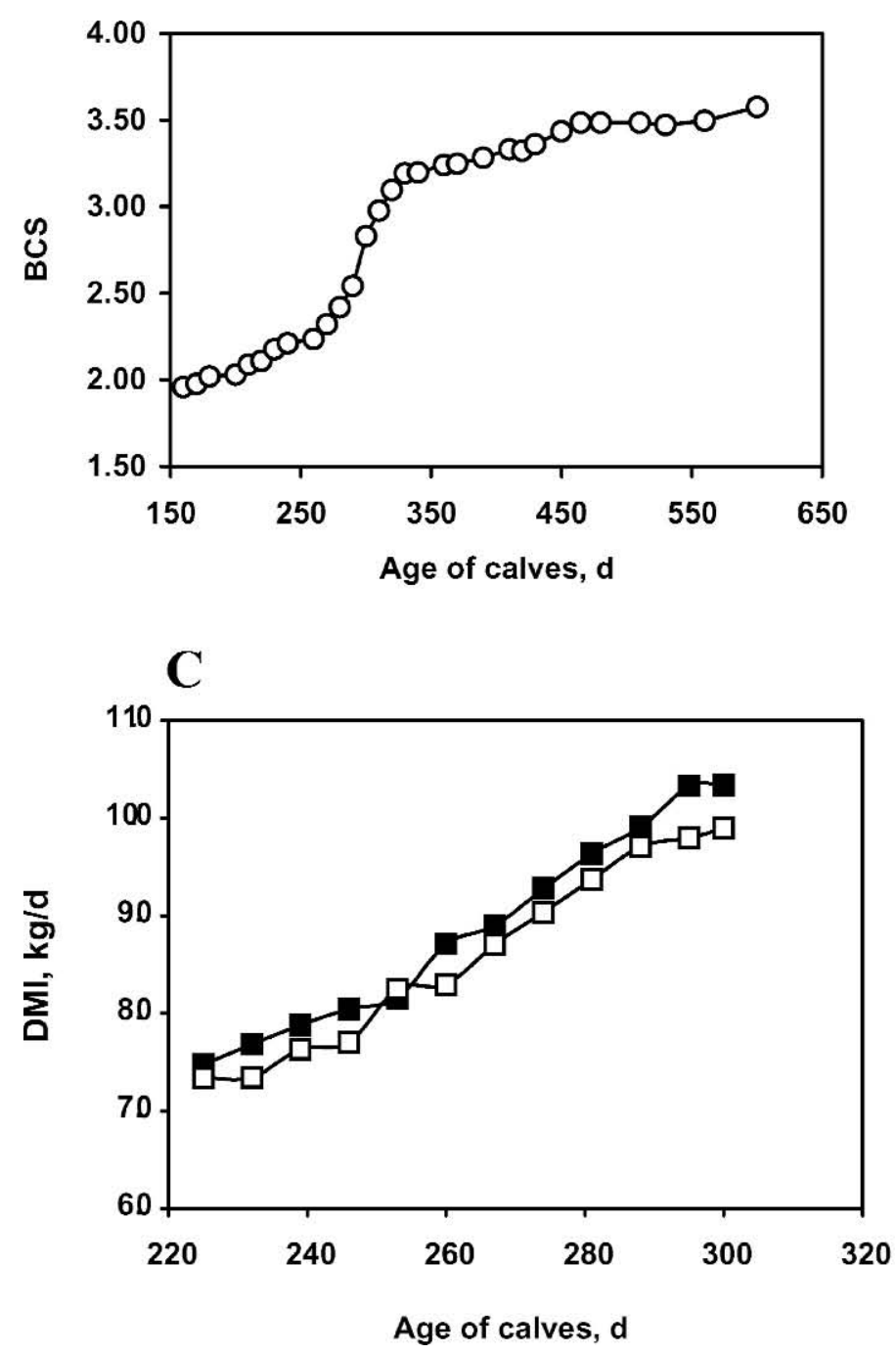

B

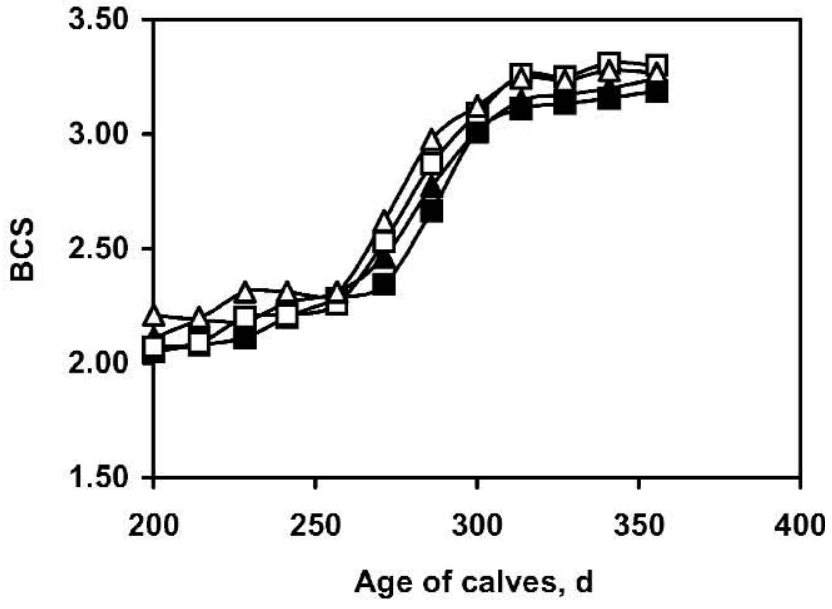

D

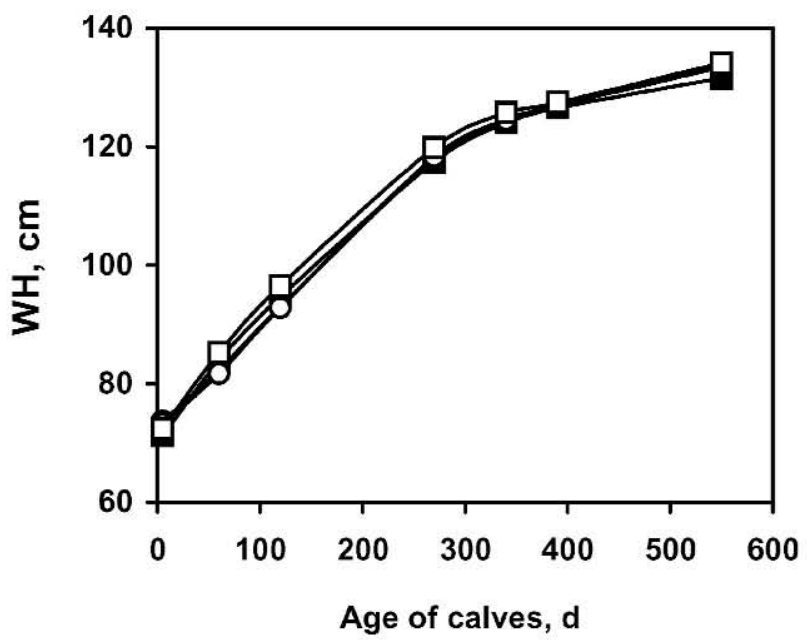

Figure 1. A) Average BCS (scale of 1 to 5) of all calves from 150 to 550 d of age. B) Average BCS (scale of 1 to 5 ) of calves in milk replacer $(\mathrm{MR})(\square), \mathrm{MR}+\mathrm{CP}(\square)$, milk-fed $(\mathrm{MF})(\mathbf{\Delta})$, and $\mathrm{MF}+\mathrm{CP}(\triangle)$ treatment groups from 200 to $350 \mathrm{~d}$ of age. C) Average DMI of calves during the period of puberty attainment that were fed rations unsupplemented ( $\square$ ) or supplemented ( $\square$ ) with $2 \%$ fishmeal protein from 180

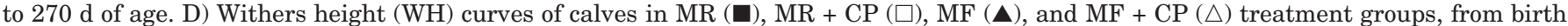
to $550 \mathrm{~d}$ of age

\section{WH}

Withers height of the MF + CP calves was greater than those of the MR and MR + CP calves from 180 to $340 \mathrm{~d}$ of age, but not at $550 \mathrm{~d}$ of age (Table $4 ; P<0.05$ ). Withers height of the MF calves was similar to that of the MF + CP calves only at $180 \mathrm{~d}$ of age. Later on, growth rate of withers in the MF calves was lower than that with the other treatments, and at $550 \mathrm{~d}$ of age, it was lower $(P<0.05)$ than in the other groups. No main effect of nursing management or of dietary protein supplementation on WH could be detected. However, the nursing management $\times$ age interaction was significant $(P<$ $0.0001)$; at $180 \mathrm{~d}$ of age, $\mathrm{WH}$ of the MF calves was greater than that of the MR calves by $2.5 \mathrm{~cm}(P<0.0001)$; at 270 and $340 \mathrm{~d}$ of age, no difference could be detected; and at $550 \mathrm{~d}$ of age, WH of the MR calves was significantly greater than that of the MF calves $(P<0.0001)$.

HG

Heart girth of the MF + CP calves was significantly greater than that of the other treatments from 180 to $550 \mathrm{~d}$ of age accept when compared with the HG of the 
Table 5. Age and BW at puberty; age, BW, and withers height (WH) at calving; and adjusted values of milk yield and composition of the heifers on treatments MR $(n=8), M R+C P(n=7), M F(n=9)$, and MF + CP $(n=10)$ during the 305 d of the first lactation. ${ }^{1}$

\begin{tabular}{|c|c|c|c|c|c|c|c|c|}
\hline & \multicolumn{4}{|c|}{ Treatment } & SEM & $P$ & \multicolumn{2}{|c|}{ Main effect } \\
\hline Age at puberty, $d$ & $286^{\mathrm{a}}$ & $258^{\mathrm{b}}$ & $284^{\mathrm{a}}$ & $264^{\mathrm{b}}$ & 8.9 & 0.02 & 0.01 & NS \\
\hline Age at calving, $d$ & 700 & 683 & 696 & 684 & 9.0 & 0.87 & NS & 0.15 \\
\hline BW $4 \mathrm{~d}$ postcalving, $\mathrm{kg}$ & 504 & 525 & 499 & 520 & 13.0 & 0.37 & NS & 0.13 \\
\hline WH at $660 \mathrm{~d}$ of age, $\mathrm{cm}$ & 137.4 & 135.2 & 137.2 & 137.4 & 0.90 & 0.12 & NS & NS \\
\hline Milk yield, kg & $10,784^{\mathrm{c}}$ & $10,916^{\mathrm{c}}$ & $11,558^{\mathrm{b}}$ & $12,104^{\mathrm{a}}$ & 365 & 0.05 & NS & 0.01 \\
\hline Daily milk fat, $\mathrm{kg} / \mathrm{d}$ & 0.96 & 1.01 & 0.99 & 1.03 & 0.017 & 0.35 & 0.01 & 0.14 \\
\hline Daily milk protein, $\mathrm{kg} / \mathrm{d}$ & 0.91 & 0.97 & 0.97 & 1.02 & 0.015 & 0.44 & 0.0003 & 0.001 \\
\hline $\begin{array}{l}\text { Daily } 3.5 \% \text { fat-corrected milk, } \\
\mathrm{kg} / \mathrm{d}\end{array}$ & $28.6^{\mathrm{c}}$ & $29.8^{b}$ & $30.0^{\mathrm{b}}$ & $31.4^{\mathrm{a}}$ & 0.45 & 0.04 & 0.005 & 0.001 \\
\hline
\end{tabular}

${ }^{\mathrm{a}, \mathrm{b}, \mathrm{c}}$ Means in a row with different letters differ $(P<0.05)$.

${ }^{1} \mathrm{MR}=$ Nursed with milk replacer; $\mathrm{MF}=$ milk-fed, nursed with an ad libitum milk supply; MR $+\mathrm{CP}=\mathrm{MR}$ diet supplemented with $2 \%$ $\mathrm{CP}$; and $\mathrm{MF}+\mathrm{CP}=$ milk diet supplemented with $2 \% \mathrm{CP}$.

MF group at $180 \mathrm{~d}$ of age (Table 4). Heart girth of the $\mathrm{MR}+\mathrm{CP}$ and MF calves was similar from 270 to $340 \mathrm{~d}$ of age and was significantly greater as compared with the MR calves. At $550 \mathrm{~d}$ of age, only HG of the MR + CP calves was significantly higher than that of the MR calves. Main effects of nursing management and of protein supplementation were significant until $270 \mathrm{~d}$ of age. The difference between MF and MR calves decreased gradually with age (nursing management $\times$ age, $P<$ 0.0001). The difference between the protein-supplemented and non-supplemented calves remained similar until $550 \mathrm{~d}$ of age (no protein $\times$ age interaction).

\section{HW}

The HW of the MF + CP calves was greater than in all other treatments at $270 \mathrm{~d}$ of age. At $340 \mathrm{~d}$ of age, it was still greater than those of the MR, MF, and MR + $\mathrm{CP}$ calves. At $340 \mathrm{~d}$ of age, no significant difference in $\mathrm{HW}$ among $\mathrm{MR}, \mathrm{MF}$, and $\mathrm{MR}+\mathrm{CP}$ groups could be discerned. There was a main effect of protein supplementation at $340 \mathrm{~d}$ of age $(P<0.01)$. No protein $\times$ age interaction was detected, but the difference between the 2 nursing managements decreased with age (nursing management $\times$ age interaction, $P<0.0001)$.

\section{Puberty Attainment}

The calves on the MR, MR + CP, MF, and MF + CP treatments reached puberty at 286.3, 283.5, 258.1, and $264.1 \mathrm{~d}$ of age, respectively (Table 5). Average age at puberty of calves from both subgroups that had been nursed with milk was $23 \mathrm{~d}$ earlier than those nursed with MR $(P<0.01)$. No main effect of protein supplementation was detected. Average BW at puberty onset of the $\mathrm{MR}, \mathrm{MR}+\mathrm{CP}, \mathrm{MF}$, and $\mathrm{MF}+\mathrm{CP}$ calves were 279 , 290, 262, and $291 \mathrm{~kg}$, respectively $(P<0.025$; Table 5$)$.

\section{Body Condition}

Changes in BCS during the rearing period are described in Figure 1 (A and B). Three phases can be defined in the average BCS curve based on the average rate of increase in BCS (Figure 1A). Phase 1, from 150 to $260 \mathrm{~d}$ of age, shows a moderate increase of 0.0027 units/d; phase 2, the next $60 \mathrm{~d}$, is characterized by a 5 fold increase in BCS of 0.0129 units/d, and phase 3 , from 330 to $580 \mathrm{~d}$ of age, displays a moderate increase of 0.0014 units/d. Phase 2 starts immediately after puberty onset. According to progesterone analyses, the average age of puberty attainment was $272 \pm 26.8 \mathrm{~d}$. This pattern of BCS increase was observed in each individual calf, independent of nutritional treatment during nursing or prepubertal periods (Figure 1B).

\section{First-Lactation Performance}

Data on first-lactation performance were summarized for 34 heifers $(8,7,9$, and 10 heifers from MR, MF, MR $+\mathrm{CP}$, and MF + CP treatments, respectively). Six heifers were withdrawn from the experiment after they proved to be pregnant, and no direct connection with the experimental treatments could be detected. Calving age was similar for all treatments and averaged $691 \pm 29.6 \mathrm{~d}$ (23.3 $\pm 1 \mathrm{mo})$. Similarly, no significant difference was found among treatments in $\mathrm{BW}$ at $4 \mathrm{~d}$ postcalving or in $\mathrm{WH}$ at $660 \mathrm{~d}$ of age (30 d before expected calving), averaging $512 \pm 35.6 \mathrm{~kg}$ and $138.0 \pm 2.22 \mathrm{~cm}$, respectively (Table 5). 


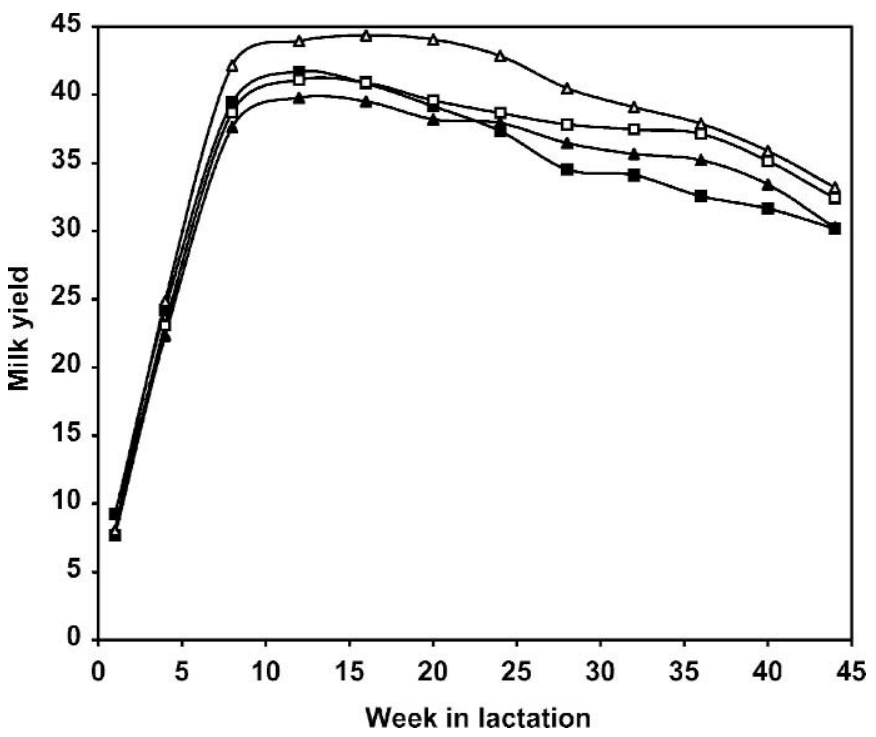

Figure 2. Adjusted milk yield (kg/d) curves of heifers in milk

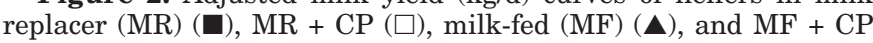
$(\triangle)$ treatment groups during $305 \mathrm{~d}$ of first lactation.

Production of the heifers during first lactation is described in Table 5 and Figure 2. Milk yield (kg) during $305 \mathrm{~d}$ of the first lactation was highest for the MF + CP heifers and was lowest for the MR and MF heifers $(P<$ 0.046). Milk yield (kg) for the MR + CP heifers exhibited medium value. Milk yield was higher by $981 \mathrm{~kg} / 305 \mathrm{~d}$ for the protein-supplemented heifers $(P<0.01)$. Percentage of milk fat was lower in the protein-supplemented treatments $(3.31 \%$ vs. $3.11 \% ; P<0.001)$. However, milk fat yield $(\mathrm{kg} / \mathrm{d})$ was increased by milk nursing $(0.98 \mathrm{vs}$. $1.02 ; P<0.007)$ and was not affected by protein supplementation. Percentage of milk protein was increased by milk nursing $(3.07 \%$ vs. $3.11 \% ; P<0.08)$ and was decreased by protein supplementation $(3.14 \%$ vs. $3.04 \%$; $P<0.001)$. Milk protein yield $(\mathrm{kg} / \mathrm{d})$ responded differently; it was increased by both main effects, by milk nursing $(0.94$ vs. $1.00 \mathrm{~kg} / \mathrm{d} ; P<0.001)$ and by protein supplementation $(0.94$ vs. $1.00 \mathrm{~kg} / \mathrm{d} ; P<0.001)$. Accordingly, $3.5 \%$ fat-corrected milk was increased by milk nursing ( 29.3 vs. $30.6 \mathrm{~kg} / \mathrm{d} ; P<0.005)$ and by protein supplementation $(29.2$ vs. $30.7 \mathrm{~kg} / \mathrm{d} ; P<0.001)$.

\section{DISCUSSION}

\section{Growth Rate During the Nursing Period}

In the current study, 2 populations of calves were developed during the nursing period that differed in BW and skeletal size at $60 \mathrm{~d}$ of age. The BW and skeletal size of the MF calves were significantly greater than those of the MR heifers, and they were heavier by 14.5 $\mathrm{kg}$ and higher at the withers by $2.6 \mathrm{~cm}$ (Table 3 ). The
MF calves consumed $9.8 \%$ more DM and $52.4 \%$ more ME from birth until $60 \mathrm{~d}$ of age than the MR calves (Table 2). Although the MR calves had free access to starter mix, and their digestive tract was expected to be more developed than that of the MF calves, they were unable to match the total DM and ME consumed by the MF calves. Similar results have been reported by BarPeled et al. (1997) for Holstein calves that had been nursed by ad libitum suckling 3 times daily for $6 \mathrm{wk}$. Their BW was $11.5 \mathrm{~kg}$ higher than that of calves nursed by commercial management of $500 \mathrm{~g} / \mathrm{d} \mathrm{MR}$. The overall energy intake by the suckling calves in the study of BarPeled et al. (1997) was 55 Mcal ME more than that of the control calves. Indeed, until the rumen reaches its adult potential for consumption and digestion, the young dairy calf can consume more nutrients and energy from liquid food (milk) than from solid food. This means that to induce maximal skeletal growth in the first months after birth, suckling or nursing with milk should be used. The suckling calves of the Bar-Peled et al. (1997) study had free access to feed, but they did not consume any concentrate or hay during the suckling period. Immediately after weaning, during wk 7, their BW decreased sharply as a result of weaning stress and adjustment to solid food. The MF calves in the present study had free access to milk twice daily only, and milk was gradually reduced during the final $10 \mathrm{~d}$. As a result, the MF calves started consuming solid food relatively early on in the nursing period and did not exhibit any stress symptoms during the transition from liquid to dry food. It was our goal to determine whether such an advantage in BW and skeletal size that was achieved at weaning would affect long-term performance during the growth period and first lactation.

\section{Attainment of Puberty}

Independent of dietary protein supplementation from 180 to $270 \mathrm{~d}$ of age, the average age at puberty onset was $23 \mathrm{~d}$ earlier in calves nursed with milk than in those nursed with MR. It is worth noting that although the BW of the protein-supplemented calves was significantly greater during the period of puberty attainment than that of the nonsupplemented calves (Table 5), this did not affect the age of puberty onset. Smith et al. (1979) raised the possibility that puberty is not a simple result of BW and body size in heifers but may also involve the attainment of a certain fat content. Peri et al. (1993) also reported that restricted heifers that were switched to an ad libitum diet shortly before puberty entered the estrous cycle $22 \mathrm{~d}$ before control heifers. Those researchers suggested that during the short compensatory growth in the ad libitum period, they fattened more relative to control heifers. When a 2 -step feeding man- 
agement program was conducted (Barash et al., 1994), puberty of the restricted heifers began during the second ad libitum period, although their BW was $28 \mathrm{~kg}$ lower than that of the control heifers. In that same study (Barash et al., 1994), it was suggested that the compensatory ration was sufficient to attain the critical body fat content needed to induce puberty, as stated by Smith et al. (1979). Note that all of these reports emphasize the nutritional status of the animal a short time before puberty onset as an important trigger for the process. In the present study, the age of puberty onset was not affected by supplementing the diet with extra CP until $270 \mathrm{~d}$ of age, but rather by nursing management 7 to 8 mo earlier. It seems that nursing ad libitum with milk might have created a physiological situation that had a long-term effect on age of puberty.

\section{BCS During Puberty}

To the best of our knowledge, there has been no systematic study of fattening patterns throughout the rearing period of dairy heifers. Body condition score, based on a 5-unit scale, is a common method of evaluating fat deposition patterns in dairy cows. Whereas the body's energy balance directly affects productivity, reproduction, health, and longevity in these animals, BCS had been proven to be a good indicator of the body fat reserves. An average increase of 0.77 BCS units during the $60 \mathrm{~d}$ following the onset of puberty was found to be an integral part of the puberty process (Figure 1, A and B). The age at which the BCS showed an accelerated increase or enhanced fat deposition coincided with puberty, regardless of treatment.

As already mentioned, many publications have reported on the connection between an animal's prepubertal energy and fattening status and its puberty onset. However, very few have dealt with fattening during puberty. Chehab (2000), in reviewing the role of leptin as a regulator of adipose mass and reproduction, concluded that as an organism grows, its adipose mass increases and, consequently, leptin levels rise naturally at puberty, creating a paradigm for the significance of adipose tissue. Similarly, during the first genital cycle in girls, leptin levels correlate with an increase in adipose tissue mass. This description could be interpreted as a short period of extra fattening connected with the puberty process, as was described in the present study for heifers.

The enhanced increase in the rate of BCS gain lasts approximately $2 \mathrm{mo}$. During this period, the skeletal growth rate of the female calf as represented by WH was reduced by nearly two-thirds, from 0.175 to 0.053 $\mathrm{cm} / \mathrm{d}$ (Figure 1D), but no change could be detected in the rate of feed intake (Figure 1C). It seems that from pre- to postpubertal period in heifers, there is an essen- tial transition in metabolism, which switched the deposition of absorbed nutrients from skeletal tissues to fat accumulation.

\section{Compensatory Growth Rate of Skeletal Size and BW}

In the present study, it was hypothesized that skeletal measurements at first calving could be affected by enhanced growth rate during the first weeks after birth, when growth potential is maximal and the tendency toward fattening is still low. Results reported by Bar Peled et al. (1997) supported this hypothesis; remarkable differences in BW and $\mathrm{WH}$ of calves at weaning, which were induced during the nursing period, existed during the entire rearing period until first calving. Results of the present study partially agree with those data. An average advantage of $16 \mathrm{~kg}$ in BW of calves nursed with milk provided ad libitum was consistent throughout the rearing period, relative to calves nursed with MR. This difference was also apparent $4 \mathrm{~d}$ postcalving but was not significant (Table 5; $P<0.365$ ). Crude protein supplementation from 180 to $270 \mathrm{~d}$ of age enhanced BW gain in both subgroups relative to their nonsupplemented counterparts (Table 4). The advantage in BW of the CP-supplemented animals increased with age until $550 \mathrm{~d}$ of age (Table 4 ), but not $4 \mathrm{~d}$ after calving (Table 5). This means that in calves that are reared from weaning to first calving on the same feeding management, no compensatory processes take place to reduce the differences in BW developed during the nursing period.

However, this was not the situation with skeletal growth. Differences in WH, HG, and HW among treatments, which were significant at weaning (Table 3), became gradually smaller, as evidenced by the nursing management $\times$ age interaction $(P<0.0001)$. Withers height of the MF heifers at $550 \mathrm{~d}$ of age was significantly lower, by $2.3 \mathrm{~cm}$, than the average of heifers from other treatments (Table 4). Heifers fed the high-protein diets during the prepubertal period had advantage in skeletal measurements until $270 \mathrm{~d}$ of age but not later (Table 4). Results of the present study suggest the existence of a compensatory mechanism for skeletal growth but not for body mass growth, and that BW responds more sensitively to changes in dietary protein than skeleton. It can be concluded that the results of the present study do not support our working hypothesis. Heifers that were reared on the same management from weaning to first calving compensated for differences in skeletal size that had developed during the nursing period, but not for differences in BW. In his review on compensatory growth, Ryan (1990) stated that if restriction were imposed during critical periods, including soon after birth, complete compensation would not be demonstrated in 
cattle. The results of the present study agree with his statement with respect to the compensatory growth of BW, but not in terms of skeletal growth.

\section{Performance of Heifers During 305 d of First Lactation}

The mean daily rate of $\mathrm{BW}$ gain in all treatments, from birth to first calving, was $0.689 \mathrm{~kg} / \mathrm{d}$ (Tables 3 and 5). Most reports agree that a BW gain of approximately $700 \mathrm{~g} / \mathrm{d}$ is optimal for maximal milk yield (Foldager and Sejrsen, 1987; Hoffman et al., 1996; Sejrsen and Purup, 1997), although others (Knight, 2001) have found no negative effects in Holsteins, up to approximately 900 $\mathrm{g} / \mathrm{d}$. High values of adjusted milk yields (Table 5 ) proved that conditions of the present experiment enabled high milk production. No main effect of nursing management on milk yield could be detected, but it affected milk fat yield and milk protein percentage and yield positively. Consequently, $3.5 \%$ fat-corrected milk yield was increased by an average of $1.3 \mathrm{~kg} / \mathrm{d}(P<0.005)$ as a result of nursing by milk. Fishmeal protein supplementation in the diet, for 3 mo prepuberty, affected milk yield and composition in a different way. Average milk yield was elevated by $3.22 \mathrm{~kg} / \mathrm{d}(P<0.047)$, whereas milk fat and protein percentages were decreased by $0.2 \%(P<0.0007)$ and $0.1 \%(P<0.001)$, respectively. Nevertheless, an average increase of $1.5 \mathrm{~kg} / \mathrm{d}$ in $3.5 \%$ fat-corrected milk $(P<0.001)$ was observed in the protein-supplemented heifers. Both main effects represent long-term effects, in which the heifers were exposed to a nutritional treatment during nursing or prepubertal periods, 20 and 14 mo before first calving, respectively. These treatments initiated probably, physiological situation essential for realizing the potential of milk production during first lactation.

The MF heifers benefited more from protein supplementation in the diet than the MR heifers; daily increases in milk and $3.5 \%$ fat-corrected milk yields, as a result of protein supplementation, were 3.8 and 1.6 as compared with 2.5 and $1.4 \mathrm{~kg} / \mathrm{d}$ in the $\mathrm{MF}+\mathrm{CP}$ and $\mathrm{MR}$ $+\mathrm{CP}$ heifers, respectively (Table 5). Similarly, the MF calves responded to additional protein by $\mathrm{WH}$ growth rate much more than the MR calves; at $550 \mathrm{~d}$ of age, $\mathrm{WH}$ of the $\mathrm{MF}+\mathrm{CP}$ calves was greater by $2.6 \mathrm{~cm}$ than the MF calves, whereas the MR and the MR + CP calves had the same WH (Table 4). This raises the possibility that requirements of the MF calves for dietary protein were greater as compared with the MR calves. These calves suffered from some deficiency that the ration of $13 \%$ CP recommended by the NRC (1989) for growing heifers could not supply. It seems that after the accelerated growth induced during the nursing period by the ad libitum milk management, a high-CP diet was essen- tial to support the metabolic processes initiated during that period.

\section{NRC 2001 Standards}

Because of conclusions that may apply to important junctions during rearing of replacement heifers, it was of interest to compare growth performance accepted in the present study to the NRC 2001 model. The MR calves that gained during this period $(0.6 \mathrm{~kg} / \mathrm{d})$ consumed an average of 3.9 Mcal ME/d (Table 2) and required, according to NRC (2001), 4.1 Mcal ME/d. The MF calves that gained $0.9 \mathrm{~kg} / \mathrm{d}$ consumed an average of $5.5 \mathrm{Mcal}$ $\mathrm{ME} / \mathrm{d}$ (Table 2) and required, according to NRC (2001), $5.9 \mathrm{Mcal} \mathrm{ME} / \mathrm{d}$. Accordingly, ME consumption of calves in the present study, in both BW gain rates, averaged 94\% of NRC (2001) recommendations. Crude protein consumption during the nursing period was a result of quantities of milk and MR that were given to the calves and the ratio of liquid to solid food consumed by the calves. Averages of CP percentage in total DMI of MR and MF calves during the nursing period were 20.0 and 25.5 (Table 2), respectively, whereas the respective values in the NRC (2001) model were 23.0 and $26.6 \%$. Accordingly, CP consumed as a percentage of NRC (2001) recommendations was 87 and $96 \%$ for 0.6 and $0.9 \mathrm{~kg} / \mathrm{d}$ $\mathrm{BW}$ gain rates. It seems that efficiencies of dietary $\mathrm{ME}$ and CP use for growth tended to be higher in the present study as compared with NRC (2001) recommendations.

Based on the database from the Purina Research Center herd, Kertz et al. (1998) suggested BW and WH reference points along rearing period. Body weight and WH gains of the MR heifers, which represent the standard recommendations of the Israeli dairy herd, were similar during the rearing period to the targeted points of Kertz et al. (1998), except for the postcalving BW. Withers height gain at 12 mo of age, which is expected to be $75 \%$ of adult gain (Kertz et al., 1998), was similar in both populations. The postcalving $\mathrm{BW}$ to $\mathrm{WH}$ ratio was narrower for the MR heifers, or the heifers in the study of Kertz et al. (1998) were heavier but not taller, than the MR heifers. Body weights of the MR heifers are typical for the Israeli cow, which is lighter than the American cow. Accordingly, the calves used in the present study and their rearing management, were optimal for getting high-yielding dairy cows.

\section{CONCLUSIONS}

Heifers reared on the same management from weaning to first calving compensated for differences in skeletal size developed during the nursing period, but heifers did not compensate for developed differences in BW. The MF calves reached puberty at an earlier age than calves 
nursed under the current practice of $450 \mathrm{~g}$ of DM/d of MR. Nursing by ad libitum milk management, as described in the present study, created a physiological basis for improved 3.5\% fat-corrected milk production by the adult heifers. Supplementing the diet with $2 \%$ CP as fishmeal during the prepubertal period enhanced $\mathrm{BW}$ gain but not skeletal size and resulted in higher milk and $3.5 \%$ fat-corrected milk yields. The increase in milk and $3.5 \%$ FCM yields of the MF calves, as a result of $\mathrm{CP}$ supplementation, was greater than that in their MR counterparts, indicating a cumulative mechanism, initiated during the nursing period and established and supported by elevating dietary CP levels during the prepubertal period.

\section{ACKNOWLEDGMENTS}

This research was supported by a grant from the United States-Israel Binational Agricultural Research and Development Fund (BARD), No. US-2921-97R.

\section{REFERENCES}

Bar Peled, U., B. Robinzon, E. Maltz, H. Tagari, Y. Folman, I. Bruckental, H. Voet, H. Gacitua, and A. R. Lehrer. 1997. Increased weight gain and effects on production parameters on Holstein heifers calves that were allowed to suckle from birth to six weeks of age. J. Dairy Sci. 80:2523-2528.

Barash, H., Y. Bar-Meir, and I. Bruckental. 1994. Effects of a lowenergy diet followed by a compensatory diet on growth, puberty and milk production in dairy heifers. Livest. Prod. Sci. 39:263-268.

Chehab, F. F. 2000. Leptin as a regulator of adipose mass and reproduction. Trends Pharmacol. Sci. 21:309-314.

Drackley, J. K. 2001. Influence of early nutrition on growth and body composition of dairy calves. Pages 25-36 in Proc. Cornell Conference for Feed Manufacturers, Ithaca, NY.

Edmonson, A. J., I. J. Lean, L. D. Weaver, T. Farver, and G. Webster. 1989. A body condition scoring chart for Holstein dairy cows. J. Dairy Sci. 72:68-78.

Ezra, E., J. I. Weller, and D. Drori. 1987. Estimation of environmental effects on milk protein content. Heker Umas 9:31-35. (In Hebrew)

Foldager, J., and K. Sejrsen. 1987. Mammary gland development and milk production in dairy cows in relation to feeding and hormone manipulation during rearing. Pages 102-115 in Research in Cattle Production: Danish Status and Perspectives. B. B. Andersen, E. Andersen, B. Jensen, P. H. Petersen, and V. Ostergard, ed. Danske Landhuusholdingsselskab, Odensk, Denmark.
Foldager, J., and K. Sejrsen. 1991. Rearing intensity in dairy heifers and the effect on subsequent milk production. National Institute of Animal Science, Report No. 693. Research Center, Foulum, Denmark..

Gardner, R. W., L. W. Smith, and R. L. Park. 1988. Feeding and management of dairy heifers for optimal lifetime productivity. J. Dairy Sci. 71:996-999.

Heinrichs, A. J., and G. L. Hargrove. 1987. Standards of weight and height for Holstein heifers. J. Dairy Sci. 70:653-660.

Hoffman, P. C. 1997. Optimum body size of Holstein replacement heifers. J. Anim. Sci. 75:836-845.

Hoffman, P. C., N. M. Brehm, S. G. Price, and A. Prill-Adams. 1996. Effect of accelerated postpubertal growth and early calving on lactation performance of primiparous Holstein cows. J. Dairy Sci. 79:2024-2031.

Hoffman, P. C., and D. A. Funk. 1992. Applied dynamics of dairy replacement growth and management. J. Dairy Sci. 75:2504-2516.

Johnson, I. D., and J. M. Obest. 1984. The effects of level of nutrition before and after 8 months of age on subsequent milk and calf production of beef heifers over three lactations. Anim. Prod. 38:57-68.

Keown, J. F., and R. W. Everett. 1986. Effect of days carried calf, days dry, and weight of first calf heifers on yield. J. Dairy Sci. 69:1891-1896.

Kertz, A. F., B. A. Barton, and L. F. Reutzel. 1998. Relative efficiencies of wither height and body weight increase from birth until first calving in Holstein cattle. J. Dairy Sci. 81:1479-1482.

Knight, C. H. 2001. Over-fed heifers need not have impaired mammary development. Page 17 in Yearbook 2001. Hannah Research Institute, Ayr, UK.

Markusfeld, O., and E. Ezra. 1993. Body measurements, metritis, and postpartum performance of first lactation cows. J. Dairy Sci. 76:3771-3777.

National Research Council. 1989. Nutrient Requirements of Dairy Cattle. Natl. Acad. Sci., Washington, DC.

National Research Council. 2001. Nutrient Requirements of Dairy Cattle. Natl. Acad. Sci., Washington, DC.

Peri, I., A. Gertler, I. Bruckental, and H. Barash. 1993. The effect of manipulation in energy allowance during the rearing period of heifers on hormone concentrations and milk production in first lactation cows. J. Dairy Sci. 76:742-751.

Ryan, W. J. 1990. Compensatory growth in cattle and sheep. Nutr. Abstr. Rev. Ser. B. 60:653-664.

SAS User's Guide: Statistics. 2000. SAS Inst., Inc., Cary, NC.

Sejrsen, K., J. T. Huber, H. A. Tucker, and R. M. Akers. 1982. Influence of nutrition on mammary development in pre- and postpubertal heifers. J. Dairy Sci. 65:845-855.

Sejrsen, K., and S. Purup. 1997. Influence of prepubertal feeding level on milk yield potential of dairy heifers: a review. J. Anim. Sci. 75:828-835.

Smith, M. F., W. C. Burrell, J. Broadway, and I. N. Wiltbank. 1979. Estrous and pregnancy in beef heifers following use of the synchromate B treatment (SBM). Theriogenology 12:183-190. 